\title{
ALTERNATIF PEMIDANAAN DENDA HARIAN (DAY FINE) DALAM MENGHADAPI OVERCAPACITY LEMBAGA PERMASYARAKATAN: STUDI PERBANDINGAN HUKUM INDONESIA - JERMAN
}

\author{
Muhammad Angga Fathurrahman'), Tri Pancarini' ${ }^{2}$, Ade Reza Rahmat \\ Hidayat $^{3)}$, Lenny Husna ${ }^{4}$ )
}

1Ilmu Hukum, IImu Sosial dan Humaniora, Universitas Putera Batam, email: pb190710012@upbatam.ac.id 2Ilmu Hukum, IImu Sosial dan Humaniora, Universitas Putera Batam, email: pb190710004@upbatam.ac.id 3IImu Hukum, IImu Sosial dan Humaniora, Universitas Putera Batam, email: pb190710011@upbatam.ac.id 3IImu Hukum, IImu Sosial dan Humaniora, Universitas Putera Batam, email: Lenny.Husna@upbatam.ac.id

\begin{abstract}
Abstrak
Kitab Undang - Undang Hukum Pidana (KUHP) Indonesia merupakan warisan negara jajahan. Wetboek van Strafrecht (WvS) tidak dapat dipungkiri bahwa aturan yang terdapat dalam kitab KUHP ini masih memiliki kekurangan dan belum mampu mengisi kokosongan hukum. Aturan pidana pokok dalam pasal 10 KUHP menyatakan pidana pokok berupa pidana mati, penjara, kurungan dan denda. Formulasi pasal pidana dalam hukum positif Indonesia memilik kecenderungan pada pidana pokok penjara. Dengan tidak seimbangnya pidana masuk dan pidana keluar mengakibatkan lembaga permasyarakatan mengalami overcapacity. Dengan terjadinya overcapacity lembaga permasyaratan membuat lembaga berwenang ini sulit untuk mampu memberikan hak - hak tahanan secara layak. Problematika ini menjadi ujian bagi penegak dan perumus undang undang untuk melakukan pembaharuan hukum dengan studi perbandingan hukum pidana. Melalui perbandingan hukum pidana alternatif KUHP Indonesia dengan KUHP Jerman dikenal German Criminal Code menemukan metode alternatif pidana yakni denda harian (day fine) sebagai alternatif pemidanaan sebagai langkah mengantisipasi overcapacity lembaga permasyarakatan.
\end{abstract}

Kata Kunci: KUHP, WvS, German Criminal Code, Perbandingan Hukum, Overcapacity. 
Program Studi Ilmu Hukum Universitas Putera Batam

\section{PENDAHULUAN}

\subsection{Latar Belakang}

Kitab Undang - Undang Hukum Pidana (KUHP) Indonesia dalam pasal 10 menjelaskan sanksi yang dapat dijatuhkan hukuman terhadap tersangka dibagi dalam 2 tahap, yakni pidana pokok dan pidana tambahan. Pidana pokok terdiri dari pidana mati, pidana penjara, pidana kurungan dan pidana denda. Sementara pidana tambahan dapat berupa pencabutan hak - hak tertentu, perampasan barang - barang tertentu dan pengumuman putusan hakim. ${ }^{1}$

Penghukuman dalam bentuk kurungan dan penjara merupakan salah satu konsep yang umum dilakukan hakim dalam menerapkan sanksi pidana. Fungsi utama dari sanksi ini tidak lain agar terpidana mendapat efek jera dari perbuatannya dengan maksud ditempatkan di lembaga permasyarakatan serta rumah tahanan negara (rutan). Namun efek domino yang timbul dari penerapan sanksi ini ialah terjadinya overcapacity yang terjadi di beberapa lembaga permasyarakatan yang tersebar di wilayah Indonesia. Polemik ini menjadi perhatian utama oleh Wakil Menteri Hukum dan HAM (Wamenkumham), Prof. Dr. Edward Omar Sharif Hiariej, S.H., M.Hum. Dalam diskusi Vaksinasi Covid-19 dari Perspektif Hukum: Hak dan Kewajiban, menjawab keresahannya bahwa penjara di hampir seluruh wilayah Indonesia mengalami overcapacity, isu ini diperparah dengan polemik paradigma terhadap pemidanaan seseorang yang menolak vaksinasi akan dipenjara. Tentu hal ini

\footnotetext{
${ }^{1}$ Teguh Prasetyo, Hukum Pidana, PT. RajaGrafindo Persada, Jakarta, 2010, hal. 117
} 
akan memperkeruh masalah kapasitas normal penjara yang layak. ${ }^{2}$ Fungsi utama lembaga permasyarakatan sebagai lembaga pengayoman narapidana beralih fungsi menjadi tempat penampungan narapidana.

Faktor terjadinya overcapacity umumnya terjadi dikarenakan imparsialitas jumlah masuk narapidana dengan narapidana keluar (bebas). Faktor lain seperti infrasruktur lembaga permasyarakatan yang kurang memadai, kurangnya sumber daya manusia bahkan banyaknya narapidana yang mengalami overstay.

Fokus utama pemerintah Indonesia untuk mengatasi masalah ini ialah dengan melakukan resolusi lembaga permasyarakatan. Mengatasi kelebihan kapasitas lapas maka pemberian sanksi penjara dapat diganti dengan pemberian remisi, cuti bersyarat hingga pembebasan bersyarat. ${ }^{3}$ Namun hal ini digunakan sebagai langkah pemidanaan opsional diluar pidana pokok, hal yang harus ditekankan ialah aturan pidana pokok harus sejalan dengan banyaknya pemidanaan, kualitas infrastruktur dan sumber daya manusia sebagai pendorong utama. Maka setiap pelanggar pidana tidak hanya berpatokan pada sanksi penjara dan kurungan saja melainkan dengan menerapkan denda.

Ketentuan pidana pokok berupa denda adalah hukuman yang memberikan beban kewajiban kepada seseorang untuk mengembalikan

\footnotetext{
${ }^{2}$ Sucahyo, N. "Wamenkumham: Penjara Penuh, Pidana Penolak Vaksin Jadi Opsi Terakhir", https://www.voaindonesia.com/a/wamenkumham-penjara-penuh-pidana-penolak-vaksin-jadi-opsiterakhir/5741553.html. Diakses tanggal 02 Januari 2021.

${ }^{3}$ Ramadhan, R. "Dicopot dari Dirjen Pas, Utami Klaim Tekan "Overcapacity" Lapas", https://nasional.kompas.com/read/2020/03/05/17395071/dicopot-dari-dirjen-pas-utami-klaimtekan-overcapacity-lapas?page=all. Diakses tanggal 02 Januari 2021
} 
keseimbangan hukum atau menebus kesalahannya dalam bentuk sejumlah uang. ${ }^{4}$ Ketentuan pidana denda tidak diatur secara umum dalam satuan KUHP maka perberlakukan ini hanya dapat ditemukan di undang - undang tertentu (Lex Specialis).

Pidana denda merupakan salah satu solusi mengantisipasi kelebihan kapasitas lembaga permasyarakatan, dengan hakim memberikan alternatif pada jenis pelanggaran pidana yang diprioritaskan pada aspek denda itu sendiri. Hal ini bisa diterapkan di Indonesia dengan mengikuti langkah KUHP Jerman yang lebih dulu menerapkan sanksi ini. Aturan denda dalam KUHP Jerman dikenal dengan istiah Day Fine (denda harian). Mekanismenya hakim akan menghitung denda harian dengan pendapatannya per hari, dikalkulasikan dengan jumlah pidana kurungan yang dijatuhkan. ${ }^{5}$ Maka aspek kewajiban menebus dosa atau kesalahan dapat tercapai.

Dari penjelasan tersebut, penulis tertarik untuk melakukan penelitian ini sebagai salah satu bentuk sumbangsih pemikiran terhadap pembaharuan hukum di Indonesia, dengan judul penelitian: "Alternatif Pemidanaan Denda Harian (Day Fine) Dalam Menghadapi Overcapacity Lembaga Permasyarakatan: Studi Perbandingan Hukum KUHP Indonesia - Jerman.”

${ }^{4}$ Teguh Prasetyo, Hukum Pidana, PT. RajaGrafindo Persada, Jakarta, 2010, hal. 123

${ }^{5}$ Andi Hamzah, Perbandingan Hukum Pidana Beberapa Negara, Jakarta, 2008, hal. 31 
Program Studi Ilmu Hukum Universitas Putera Batam

\section{METODE PENELITIAN}

Metodologi dari setiap penelitian hukum adalah tentang cara menguraikan bagaimana suatu penelitian hukum itu harus dilakukan. ${ }^{6}$ Mengingat permasalahan yang diangkat terkait kebijakan, terfokus pada aturan pemidanaan, maka pendekatan yang dilakukan adalah pendekatan Yuridis Normatif. Karena bermanfaat untuk lebih memahami dan mengambangkan hukum pidana nasional maka pendekatan studi perbandingan hukum dilakukan melalui studi KUHP masing - masing negara dengan menitikberatkan pada asas dan delik yang tertera pada setiap pasal kemudian melakukan interpretasi pada setiap persamaan dan perbedaan diantaranya. Adapun tipe penelitian yang digunakan untuk penelitian ini menggunakan tipe penelitian deskriptif. Penelitian yang guna memecahkan masalah yang ada sekarang (kontemporer) dengan melakukan pengumpulan, penyusunan, analisi dan interpretasi dari hasil kajian yang dibahas. Mengingat tema permasalahan ini dilakukan dengan pendekatan Yuridis Normatif, maka penelitian hukum dilakukan dengan meneliti bahan Pustaka dan data sekunder.

a. Data Sekunder dalam penelitian ini:

1) Bahan hukum primer, yaitu bahan - bahan hukum yang mempunyai kekuatan mengikat ${ }^{7}$ antara lain:

a) Kitab Undang - Undang Hukum Pidana (KUHP) Indonesia

b) Kitab Undang - Undang Hukum Pidana (KUHP) Jerman (Strafgesetzbuch)

\footnotetext{
${ }^{6}$ Bambang Waluyo, Penelitian Hukum Dalam Praktek, Sinar Grafika, Jakarta, 1996, hal. 17

${ }^{7}$ Amiruddin dan Zainal Asikin, Pengantar Metode Penelitian Hukum, Jakarta, 2003, hal. 31
} 
2) Bahan hukum sekunder, yaitu bahan - bahan yang erat hubungannya dengan bahan hukum primer antara lain:

a) Rancangan Kitab Undang - Undang Hukum Pidana (RKUHP)

b) Hasil karya ilmiah (makalah, jurnal dan media internet)

\section{HASIL PENELITIAN DAN PEMBAHASAN}

\subsection{Overcapacity Lembaga Permasyarakatan Sebuah Problematika Lama}

Melalui SK Menteri Kehakiman RI No. 02-PK.04.10 Tahun 1990 Tentang Pola Pembinaan Narapidana/Tahanan, menyebutkan bahwa lembaga permasyarakatan (lapas) bukan hanya berfungsi sebagai sebuah institusi dari sistem peradilan pidana yang bertugas memberikan pembinaan narapidana saja, melainkan jauh lebih kompleks dengan diberi wewenang lebih sebagai lembaga pendidikan bertujuan memberikan sumbangsih strategis pembangunan nasional. $^{8}$

Paradigma lembaga permasyaratakan yang memiliki fungsi ganda, maka lapas saat ini memiliki fungsi berbeda dibandingkan fungsi penjara yang hanya sebagai tempat pembinaan saja. Bergerak sebagai lembaga pendidikan nasional mutu lapas untuk melakukan pemberdayaan napi ialah dengan membentuk karakter baru serta menjadikan sosok manusia yang berkualitas akhlak dan moral, yakni berpedoman pada ketuhanan yang maha esa,

\footnotetext{
${ }^{8}$ Angkasa, "Over Capacity Narapidana di Lembaga Pemasyaratakan, Faktor Penyebab, Implikasi Negatif, Serta Solusi Dalam Upaya Optimalisasi Pembinaan Narapidana”, dalam Jurnal Dinamika Hukum, Vol. 10 No. 3, September 2010, hal. 2.
} 
kemanusiaan yang adil serta beradab, berkepribadian mandiri, jujur dan memiliki kesadaran bermasyarakat.

Waktu berjalan cepat sehingga demand and supply yang tidak berimbang dari hubungan narapidana dengan insfrastruktur lapas akan mengalami disfungsi institusi. Optimalisasi fungsi dasar institusi lapas sebagai lembaga pembina dan pendidikan mengalami keuzuran kualitas dengan membludaknya narapidana masuk yang tidak diikuti jumlah pembina lapas maupun infrastruktur yang memadai maka munculah problematika kelebihan kapasitas (overcapacity).

Penjelasan menurut Menteri Hukum dan HAM pada tahun 2008, Andi Matalatta bahwa lembaga permasyarakat sudah mengalami over capacity akibat hal ini fungsi lapas tidak berjalan optimal. Penghuni lapas di seluruh Indonesia mencapai 130.832 ribu orang dengan rincian 54.307 tahanan dan 76.525 napi. Jumlah tersebut tak berimbang dengan kapasitas lapas yakni 81.384 ribu orang saja, sehingga over capacity terjadi hampir $45 \%$ dari batas normal. $^{9}$

Pemimpin Pemerintahan terus berganti dan Menteri terus mengalami pergeseran kabinet namun masalahnya masih sama. Overcapacity lapas menjadi sebuah agenda rutin rapat kerja khususnya Menteri Hukum dan HAM Republik Indonesia. Berkaca pada penjelasan Andi Matalatta yang notabene menjabat sebagai Menteri yang sama pada tahun 2008 telah

\footnotetext{
${ }^{9}$ Setiawan, A. "LP di Indonesia Over Capacity 45\%", https://news.okezone.com/read/2008/01/04/1/72751/lp-di-indonesia-over-capacity-45. Diakses pada 03 Januari 2021.
} 
Program Studi Ilmu Hukum Universitas Putera Batam

mengalami masalah ini, pun di tahun 2020 Menkumham Yasonna H Laoly mengakui kenaikan jumlah narapidana setiap tahun berada di angka 20\%, sehingga over crowding sebesar 102\% mengakibatkan kondisi lapas menjadi over kapasitas. ${ }^{10}$ Artinya bahwa masalah tentang kelebihan kapasitas (overcapacity) lembaga permasyarakatan bukanlah problematika baru melainkan sebuah probelmatika warisan yang terus - menerus menjadi topik perbincangan hangat.

\subsection{Data Lembaga Permasyarakatan di Indonesia}

Wakil Menteri Hukum dan HAM (Wamenkumham), Edward Omar Sharief Hiariej dalam pandangannya tentang overcapacity lembaga permasyarakatan menyatakan perlu adanya konsolidasi bersama para penegak hukum. ${ }^{11}$

Hal yang sama juga disampaikan oleh Wakil Ketua MPR RI, Lestari Moerdijat mengingatkan kepada pemerintah untuk terus meningkatkan perhatian pengelolaan lembaga permasyaratakan (lapas) sebagai sebuah isu yang hidup selama bertahun - tahun. ${ }^{12}$ Ketika tiap-tiap lembaga satu suara untuk mengatasi isu overcapacity ini, Kepala Ditjen PAS Kementerian Hukum

\footnotetext{
${ }^{10}$ Hidayat, R. "Upaya Kemenkumham Atasi Persoalan Over Kapasitas Lapas", https://www.hukumonline.com/berita/baca/lt5e54f2a39fdd4/upaya-kemenkumham-atasipersoalan-over-kapasitas-lapas/. Diakses pada 03 Januari 2021.

${ }^{11}$ Suwiknyo, E. “Overcapacity Lapas Disorot, Wamenkumham Beri Jawaban Begini”, https://kabar24.bisnis.com/read/20210131/16/1350152/overcapacity-lapas-disorotwamenkumham-beri-jawaban-begini. Diakses pada 03 Januari 2021

${ }^{12}$ Fajriani, D. "MPR Minta Kelebihan Kapasitas Lapas Segera Dicarikan Solusi”, https://mediaindonesia.com/politik-dan-hukum/308042/mpr-minta-kelebihan-kapasitas-lapassegera-dicarikan-solusi. Diakses pada 03 Januari 2021
} 
Program Studi Ilmu Hukum Universitas Putera Batam

dan HAM, Akbar Hadi Prabowo. Menjabarkan empat (4) faktor yang memicu terjadinya overcapacity diantaranya:

1. Faktor Kejahatan

2. Faktor proses penahanan (pre-trial detention)

3. Faktor penerimaan narapidana yang tidak semua dengan kapasitas

4. Faktor perundang - undangan ${ }^{13}$

Berdasarkan data dari sistem database permasyarakatan perkanwil di seluruh Indonesia pada periode Januari 2019 - 2021, menunjukkan data yang signifikan.

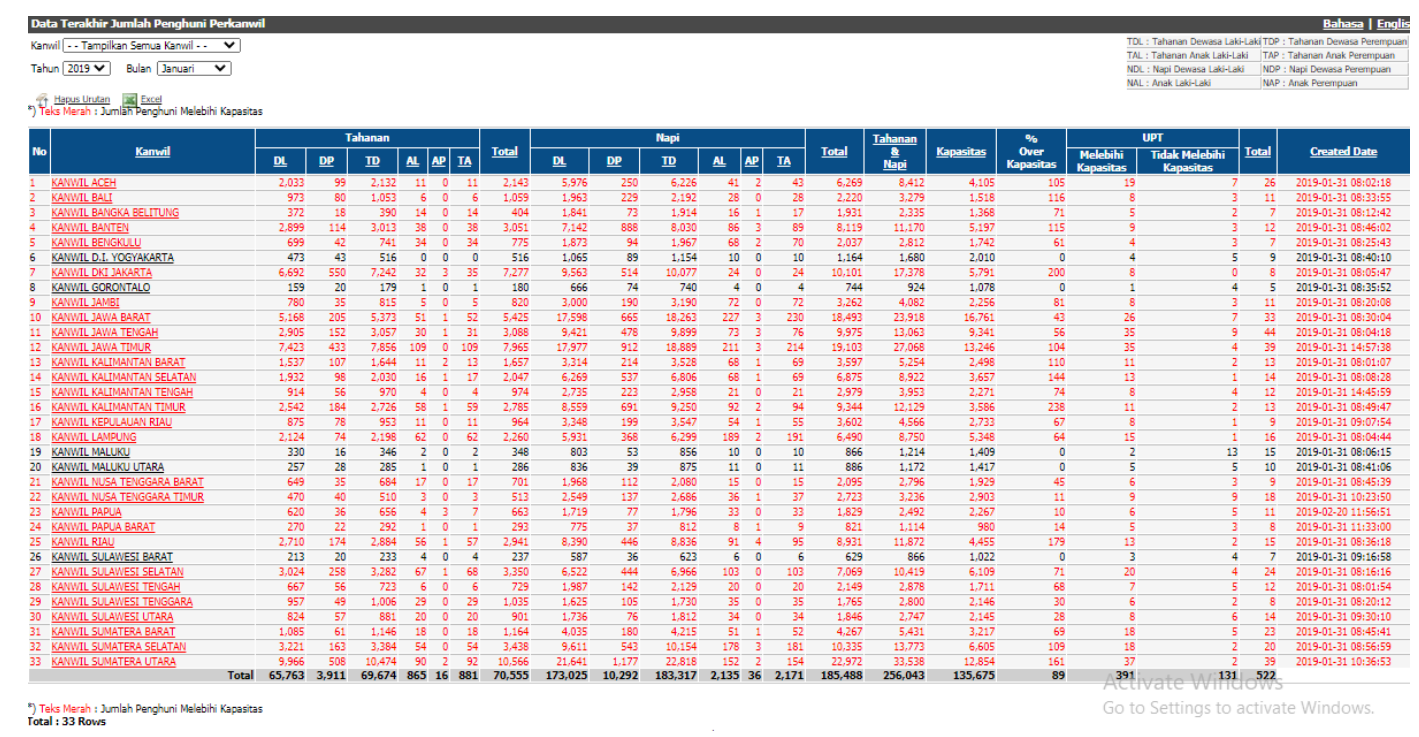

Tabel 11 Data Kanwil Lapas Indonesia Januari 2019

\footnotetext{
${ }^{13}$ Mihardi. "Ditjen Pas Ungkap Empat Penyebab Lapas Kelebihan Kapasitas.”, https://nasional.sindonews.com/berita/1161936/13/ditjen-pas-ungkap-empat-penyebab-lapaskelebihan-kapasitas. Diakses pada 04 Januari 2021.
} 


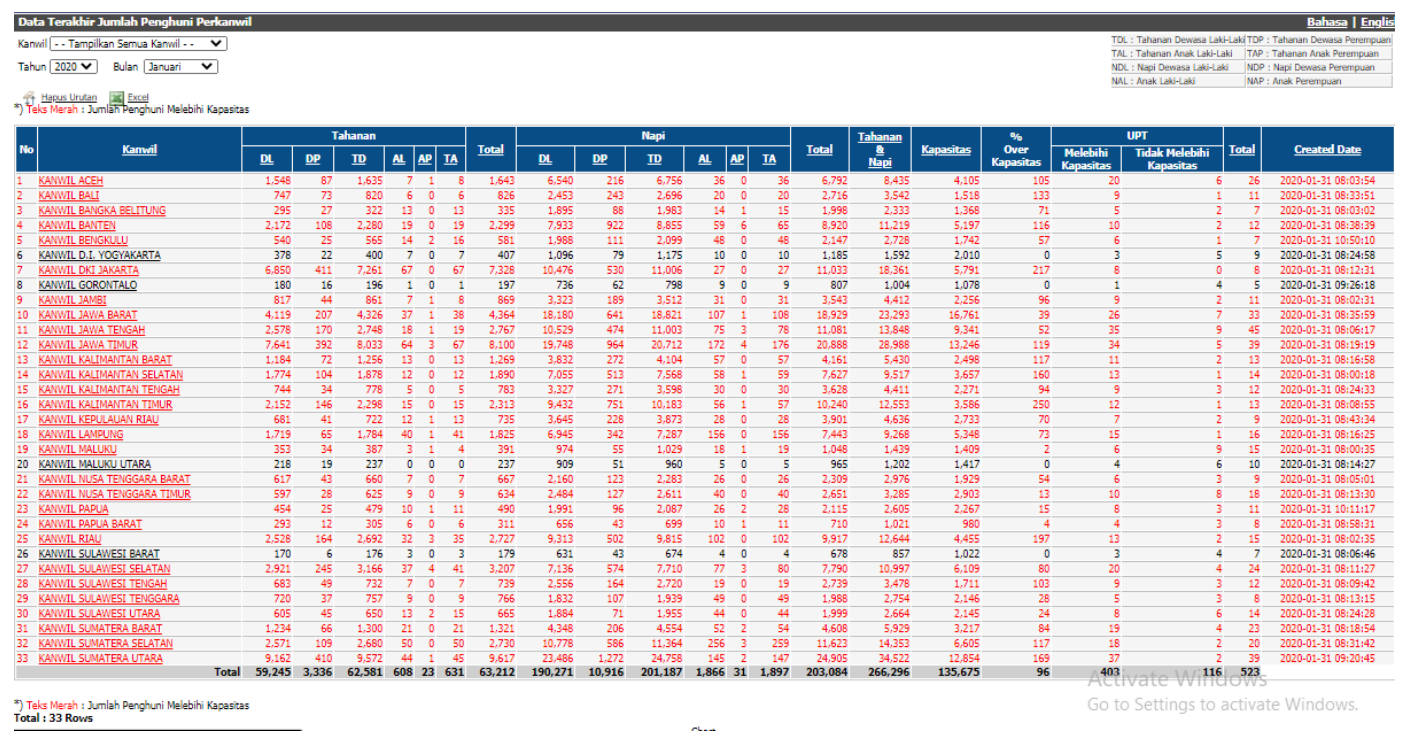

Tabel 12 Data Kanwil Lapas Indonesia Januari 2020

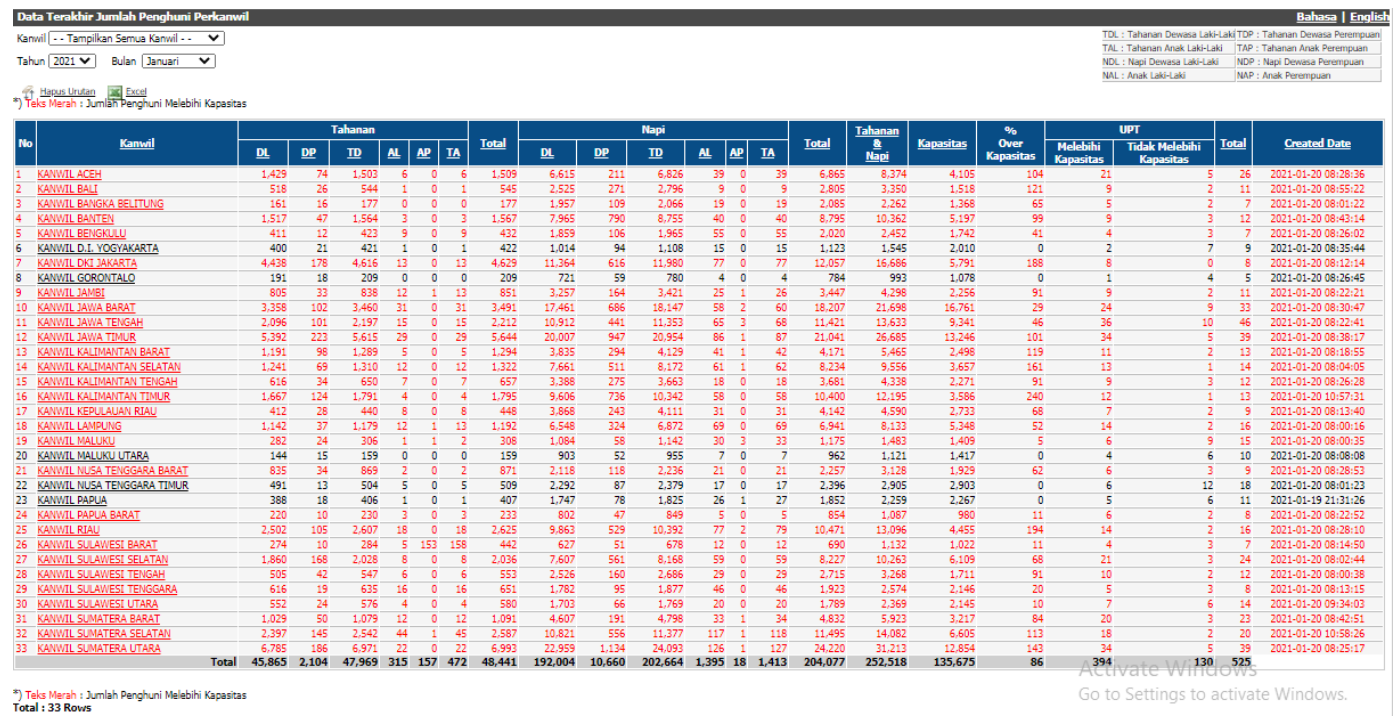

Tabel 13 Data Kanwil Lapas Indonesia Januari $2021^{14}$

Dari data tabel pada januari 2019 hanya terdapat 5 (lima) kanwil dinyatakan tidak mengalami kelebihan kapasitas yakni kanwil D.I Yogyakarta,

\footnotetext{
${ }^{14}$ Sistem Database Permasyaratakan Data Penghuni terakhir Perkanwil.

http://smslap.ditjenpas.go.id/public/grl/current/monthly. Diakses pada 20 Januari 2021
} 
Program Studi Ilmu Hukum Universitas Putera Batam

Gorontalo, Maluku, Maluku Utara dan Sulawesi Barat. Sisanya 28 kanwil mengalami overcapacity.

Tabel pada januari 2020 menunjukan kenaikan signifikan terhadap jumlah tahanan yang masuk, dari 33 kanwil hanya 4 (empat) dinyatakan bebas overcapacity yakni kanwil D.I Yogyakarta, Gorontalo, Maluku Utara dan Sulawesi Barat.

Baru pada tahun 2021 bulan Januari terdapat 2 (dua) kanwil yang pada dua tahun terakhir mengalami overcapacity baru pada tahun 2021 bebas dalam masalah kelebihan kapasitas yakni kanwil Nusa Tenggara Timur dan Papua. Diikuti oleh 3 (tiga) kanwil lain yakni D.I Yogyakarta, Gorontalo dan Maluku Utara yang berturut dalam kurun 3 tahun terakhir tidak mengalami masalah overcapacity.

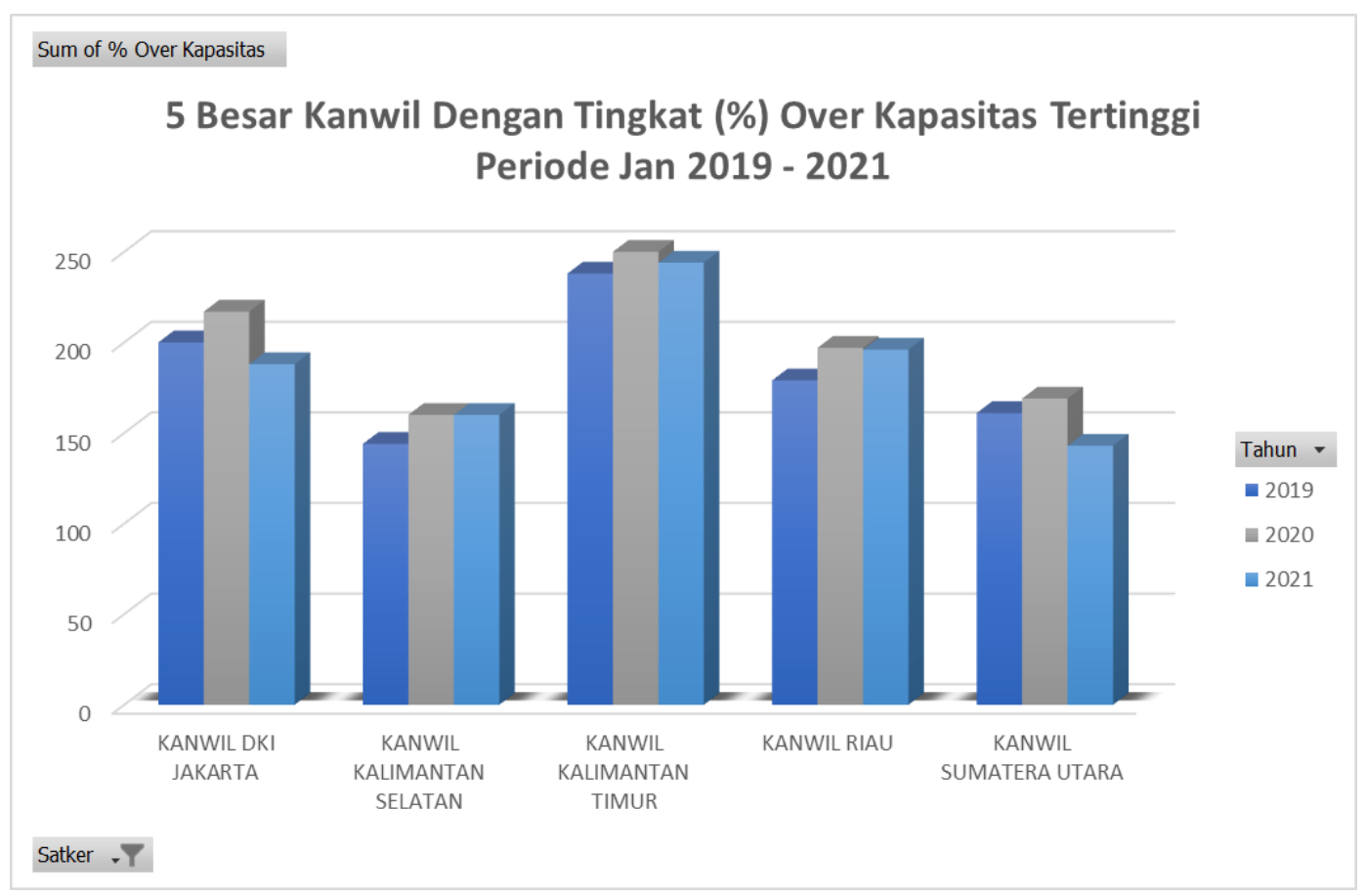


Program Studi Ilmu Hukum Universitas Putera Batam

\section{Tabel 145 (lima) Besar Kanwil Dengan Tingkat (\%) Over Kapasitas}

Tetinggi Peiode Jan 2019 - 2021

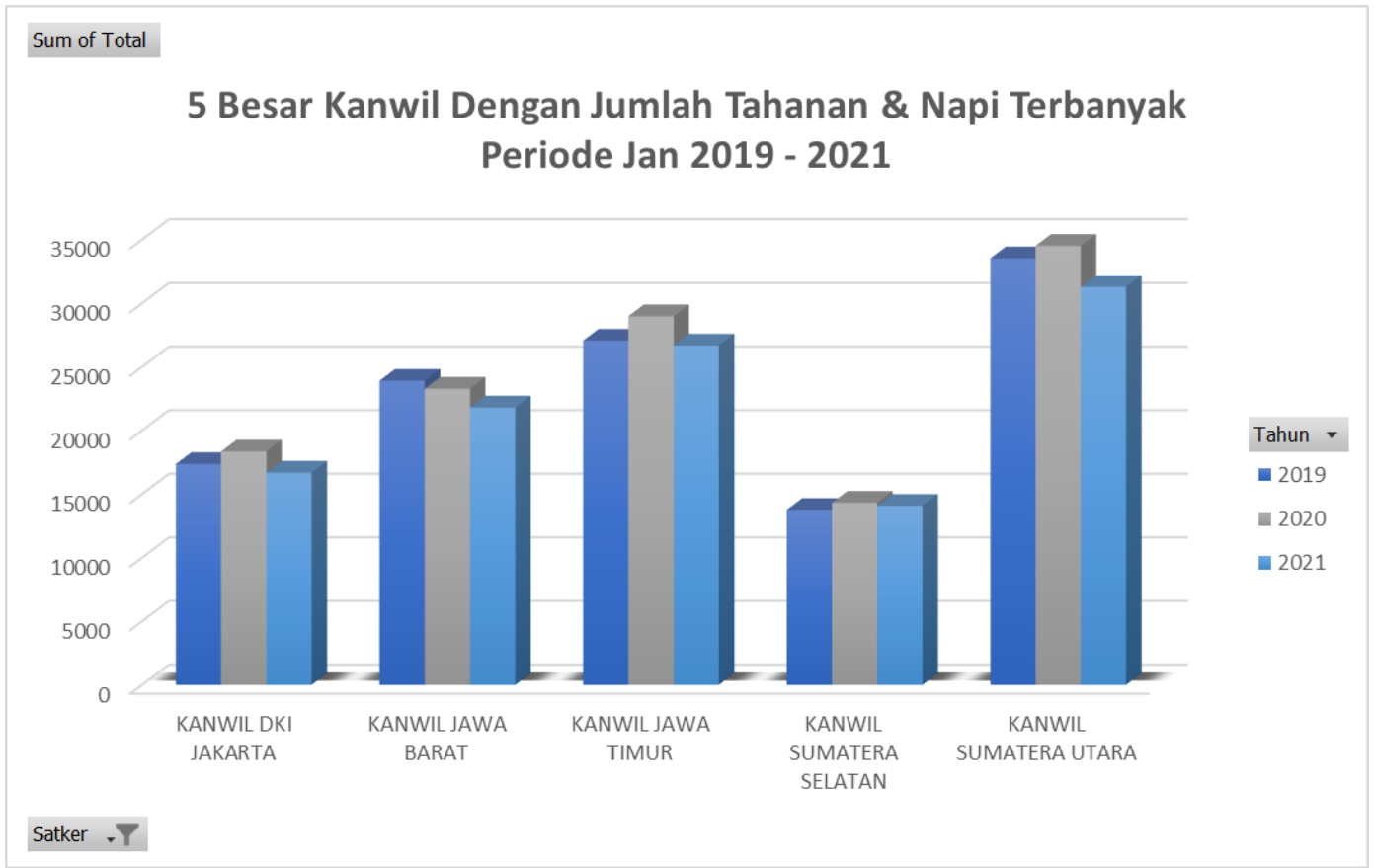

Tabel 155 (lima) Besar Kanwil Dengan Jumlah Tahanan \& Napi Terbanyak Periode Jan 2019 - 2021

Problematika overcapacity sudah masuk dalam tahap extreme, tinggal menunggu waktu yang tepat untuk meledak. Dengan terjadinya kelebihan kapasitas hampir seluruh wilayah di Indonesia, akan memperburuk kondisi para tahanan dan narapidana binaan lembaga permasyarakatan. Dalam mewujudkan narapidana yang baik setelah dinyatakan bebas, penegak hukum dan pengelola lapas harus memperhatikan faktor kapasitas yang mempengaruhi kondisi secara psikologis.

Menurut Soerjono Soekanto, tolak ukur kefektifan hukum dipengaruhi oleh beberapa faktor, antara lain: 

a. Faktor Hukum (Positif)
b. Faktor Penegak Hukum
c. Faktor Sarana
d. Faktor Masyarakat
e. Faktor Adat dan Kebudayaan ${ }^{15}$

Maka dari itu seyoginya untuk mengatasi masalah overcapacity harus diselesaikan bersama dengan satu formulasi. Lebih dari itu penegak hukum harus saling bersinergi satu suara menegakkan hukum dengan pemberian pidana alternatif yang termasuk dalam satuan pidana pokok. Ketika dua (2) faktor untuk saling bekerja sama, faktor yang berada di bawahnya akan saling mengikuti arus sehingga pemidanaan yang rasional dapat dicapai.

\subsection{Solusi Alternatif Pemidanaan Dikaji Dalam Konsep Perbandingan Hukum KUHP Indonesia - Jerman}

Indonesia diluar aturan pidana pokok juga telah terdapat ketentuan pidana alternatif selain penjara. Namun, penerapannya belum maksimal karena ketentuan umum dalam KUHP tidak mengatur secara spesifik atas itu. Hanya melalui Undang - Undang Khusus (Lex Specialis) pidana pokok denda menjadi pemidanaan tunggal.

Sebagai bentuk kajian perbandingan, KUHP negara Prancis menggunakan pidana denda secara kumulatif dalam pasal 136 yang berbunyi:

\footnotetext{
${ }^{15}$ Soerjono Sekanto, Faktor - Faktor yang Mempengaruhi Penegakan Hukum, Jakarta, Raja Grafindo Persada, 2007, hlm. 05.
} 
Pendandatangan, pengeluaran, meneruskan sebagai pembayaran dengan maksud menambah atau mengganti uang yang sah, diancam dengan pidana tutupan dari satu sampai 5 (lima) tahun dan denda dari 200.000 sampai 20.000.000 franc. $^{16}$

Ketentuan pidana pasal 136 KUHP Prancis menggunakan sistem Kumulatif - alternatif dalam perumusannya menggunakan penjatuhan hukuman tunggal. Sistem ini disebut sistem campuran, namun kewenangan hakim masih dikedepankan dengan memerikan kebebasan terkait jenis pidana yang paling sesuai. ${ }^{17}$ Hal ini terjadi penolakan dalam hukum positif di Indonesia karena ketentuan kumulasi pidana pokok (denda) hanya dapat dijatuhkan dalam satuan pidana tambahan, hal ini berguna untuk memberat pidana pokok. ${ }^{18}$

Ketentuan pidana denda dalam KUHP lebih menitikberatkan kepada perbuatan kejahatan oleh pelaku yang telah mendapat keuntungan dari peristiwa pidana. Seperti pada pasal 261 KUHP ayat 1 menyatakan:

Barang siapa yang menyimpan bahan atau benda, yang diketahui bahwa diperuntukkan untuk melakukan salah satu kejahatan yang diterangkan pasal 253, atau dalam pasal 260, diancam dengan pidana penjara paling lama 9 bulan atau denda maksimum tiga ratus rupiah. ${ }^{19}$

\footnotetext{
${ }^{16}$ Romli Atmasasmita, Perbandingan Hukum Pidana, Op.Cit., hal. 50.

${ }^{17}$ Dwi Endah Nuhayati, Tesis: "Sistem Pidana Denda Dalam Kebijakan Legislatif di Indonesia" (Semarang: Universitas Diponegoro, 2009), hal. 128.

${ }^{18}$ Dwi Endah Nuhayati, Tesis: "Sistem Pidana Denda Dalam Kebijakan Legislatif di Indonesia" (Semarang: Universitas Diponegoro, 2009), hal. 129.

${ }^{19}$ S.R. Sianturi, Tindak Pidana Di KUHP Berikut Uraiannya, Jakarta, 2019, hal 409.
} 
Bentuk pidana denda adalah penghukuman dengan perampasan kemerdekaan finansial, yang berpandangan bahwa tiada seorang pun boleh mendapat keuntungan dari perbuatan kejahatan yang telah dilakukan. (ne malis expediat esse malos $)^{20}$

Usaha untuk mencari alternatif dari pidana penjara dari penal policy terus dilakukan, salah satunya pelaksanaan pidana denda pada individu. ${ }^{21}$ Negara Jerman melalui German Criminal Code menerapkan denda harian (day fine) sebagai alternatif pidana penjara, dengan melakukan perhitungan besar denda pada pendapatan pelanggar itu sendiri. Untuk melakukan kumulasi denda harian individualis hakim berpatokan pada:

a. Kesalahan dinyatakan dan dikonversi dalam pidana penjara harian

b. Denda harian dihitung sesuai pendapatan per bulan

c. Utang yang dimiliki dikurangkan

d. Jumlah itu dibagi jumlah hari/bulan

e. Jumlah yang telah ditentukan kemudian dikalikan sehingga diperoleh jumlah denda yang harus dibayarkan. ${ }^{22}$

Ketentuan denda harian dalam German Criminal Code dipertegas dalam pasal 40 yang menyatakan:

A fine is imposed in daily rates. The minimum fine is five and, unless otherwise providedby law, the maximum is 360 full daily rates. The court determines the amount of the daily rate having regard to the offender'spersonal and financial circumstances. In doing so, it typically

${ }^{20}$ Andi Hamzah, Sistem Pidana dan Pemidaan Indonesia, Jakarta, 2009, hal 29.

${ }^{21}$ Andi Hamzah, Perbandingan Hukum Pidana Beberapa Negara, Jakarta, 2008, hal. 16.

${ }^{22}$ Ibid. hal. 31 
bases its assessment on theaverage net income which the offender earns or could earn in one day. A daily rate is set atno less than 1 euro and no more than 30,000 euros. The offender's income and assets and other relevant assessment factors may beestimated when setting the amount of the daily rate. The number and amount of the daily rates are indicated in the decision.

(Denda dikenakan dalam tarif harian. Denda minimum adalah lima dan, kecuali ditentukan lain menurut hukum, maksimum 360 tarif harian penuh. Pengadilan menentukan jumlah tarif harian yang berkaitan dengan pelanggar keadaan pribadi dan keuangan. Dalam melakukannya, biasanya mendasarkan penilaiannya pada pendapatan bersih rata-rata yang diperoleh atau bisa diperoleh pelaku dalam satu hari. Tarif harian ditetapkan tidak kurang dari 1 euro dan tidak lebih dari 30.000 euro. Pendapatan dan aset pelaku dan faktor penilaian relevan lainnya mungkin diperkirakan saat mengatur jumlah tarif harian. Jumlah dan besaran tarif harian ditunjukkan dalam keputusan)

Melalui Rancangan Kitab Undang - Undang Hukum Pidana (RKUHP) konsep yang sama dengan KUHP Jerman disebutkan dalam pasal 80 menyatakan:

Dalam menjatuhkan pidana denda, hakim wajib mempertimbangkan kemampuan terdakwa dengan memperhatikan penghasilan dan pengeluaran terdakwa secara nyata. 
Kemudian batasan dalam masa pembayaran ditentukan dalam pasal 81 ayat 1 dan 2 menyatakan:

Pidana denda wajib dibayar dalam jangka waktu tertentu yang dimuat dalam putusan pengadilan. (81 ayat 1$)$

Putusan pengadilan sebagaimana dimaksaud pada ayat (1) dapat menentukan pembayaran denda dengan cara mengangsur. (81 ayat 2)

Kelemahan dasar dari denda pidana ialah dapat dialihkan kepada pihak ketiga, maka dari itu KUHP Jerman mengantipasi hal ini dengan mewajibkan pembayaran denda dilakukan sendiri oleh pelaku. Maka Yurisprudensi Jerman mengenal istilah einheilige Meinung bahwa pembayaran oleh pihak ketiga tidak diperkenankan. ${ }^{23}$

Ketentuan dalam penerapan denda tunggal jika benar diundangkan sebagai hukum positif di Indonesia harus melihat aspek yang sangat kompleks, utamanya sendi perekomonian dan diskriminasi orang miskin. Karena jika dibenarkan dengan alasan tidak mampu membayar, maka berlaku Quinon potest solver poenam in aere, luat in corpore (siapa tidak mampu membayar, maka ia harus melunasi dengan derita badan). ${ }^{24}$

Sistem pemidanaan alternatif denda merupakan salah satu solusi mengantisipasi permasalahan overcapacity di lembaga permasyarakatan, lebih dari itu perlu juga kajian lebih spesifik untuk menerapkan pidana denda

\footnotetext{
${ }^{23}$ Jan Remmelink, Hukum Pidana: Komentar Atas Pasal - Pasal Terpenting Dari Kitab Undang - Undang Belanda dan Padanannya Dalam KUHP Indonesia, Op.cit. hal. 487. ${ }^{24}$ Dwi Endah Nuhayati, Tesis: "Sistem Pidana Denda Dalam Kebijakan Legislatif di Indonesia" (Semarang: Universitas Diponegoro, 2009), hal. 189.
} 
karena aturan pemidanaan seyoginya dibentuk demi melindungi kepentingan negara, umum, individu dan hak asasi manusia.

\section{PENUTUP}

\subsection{Simpulan}

Berdasarkan pembahasan terhadap alternatif pemidanaan Denda Harian (Day Fine) dalam menghadapi overcapacity lembaga permasyarakatan: studi perbandingan hukum KUHP Indonesia - Jerman dengan melakukan korelasi kebijakan penetapan rumusan pidana denda, ancaman serta kebijakan dalam menentukan pidana ini dalam aturan yang termuat di KUHP dan di luar KUHP. Maka kesimpulan yang dapat diambil diantaranya:

1. Problematika tentang overcapacity lembaga permasyarakatan adalah hal yang serius menyangkut aspek kemanusiaan. Lembaga penegak hukum dinilai lamban mengatasi permasalahan ini dikarenakan isu pembahasan tidak terlalu menarik bagi publik luas. Namun sebagai bentuk keefektifan hukum maka antisipasi kelebihan kapasitas bisa dilakukan dengan konsolidasi antara lembaga berwenang sehingga permasalahan ini segera menemukan titik terang.

2. Kebijakan Sistem KUHP Indonesia (Hukum Positif), masih belum kompleks mengatur aturan pemidanaan pidana pokok denda. Kebijakan masih terbatas pada sanksi yang tunggal tanpa dibarengi sanksi pidana pokok lainnya. 
3. Rancangan Kitab Undang - Undang Hukum Pidana (RKUHP) menjadi angin segar pembaharuan hukum pidana untuk mengantisipasi masalah overcapacity. Namun penerapannya menjadi hukum positif memerlukan waktu yang panjang untuk bisa melihatnya. Sebagai solusi jangka pendek maka pendekatan restorative juctice dinilai sebagai cara terbaik mengantisipasi setiap perkara pidana berakhir dengan putusan penjara.

4. Konsep perbandingan hukum KUHP Indonesia dengan Jerman memberikan sebuah petunjuk bahwa ketentuan - ketentuan yang ada dalam KUHP saat ini harus segera dibenahi untuk mengisi kekosongan hukum. Dengan pengetahuan yurisprudensi dari KUHP Jerman melalui German Criminal Code memberikan sebuah alternatif pemidanaan yakni denda harian (day fine). Hal inilah yang coba ditiru dalam RKUHP sebagai sebuah pembaharuan hukum.

\subsection{Saran}

Sebagai sebuah langkah alternatif pembaharuan hukum pidana, penetapan pidana pokok denda harus dilakukan secara konsisten dengan beraspek keadilan sosial. Dari penetapan sanksi pidana ini perlu kehati-hatian dalam menerapkannya maka KUHP yang akan datang perlu melakukan penelitian sosial masyarakat agar jika diundangkan menjadi ius constitutum tidak menimbulkan polemik. Dari penjabaran itu, maka penulis memberikan saran berupa:

1. Sebelum menerapkan sebuah pelanggaran pada sistem publik, maka masyarakat haru ikut serta. 
2. Penerapan sanksi pidana bisa dilakukan pada pelaanggaran dan kejahatan individu dengan maksimal ancaman pidana 5 (lima tahun) hakim dapat menentukan memberikan kepada pelaku sanksi pidana atau sanksi denda.

3. Seperti yang diterapkan oleh negara Jerman melalui einheilige Meinun pembayaran pidana denda harus dilakukan oleh si pelaku sendiri tidak boleh diwakilkan sebagai bentuk keadilan. Lebih dari itu, penentuan jumlah pidana harus dirumuskan lebih konkrit dan spesifik supaya penjatuhan vonis denda sesuai dengan kemampuan finansial dari pelaku.

\section{DAFTAR PUSTAKA}

Prasetyo, Teguh. 2016. Hukum Pidana. Edisi ke-7. PT RajaGrafindo Persada. Jakarta.

Hamzah, Andi. 2009. Perbandingan Hukum Pidana Beberapa Negara. Edisi ke-3. Sinar Grafika. Jakarta.

Sianturi. 2019. Tindak Pidana di KUHP Berikut Uraiannya. Edisi ke-1. Alumni AHM-PTHM. Jakarta.

Hiariej, Eddy. Prinsip - Prinsip Hukum Pidana. Edisi ke-2. Cahaya Atma Pustaka. Yogyakarta.

Hamzah, Andi. 1986. Sistem Pidana dan Pemidanaan di Indonesia: dari Retribusi ke Reformasi. Edisi ke-7. Pradnya Paramita. Jakarta.

Remmelink, Jan. 2003. Hukum Pidana: Komentar Atas Pasal-Pasal Terpenting Dari Kitab Undang - Undang Hukum Pidana Belanda dan Padanannya Dalam Kitab Undang - Undang Hukum Pidana Indonesia. Edisi ke-4. PT Gramedia Pustaka Utama. Jakarta.

Atmasasmita, Romli. 2000. Perbandingan Hukum Pidana. Edisi ke-2. Mandar Maju. Bandung.

Soekanto, Seorjono. 2002. Faktor - Faktor yang Mempengaruhi Penegakan Hukum. Edisi ke-1. PT RajaGrafindo Persada. Jakarta.

Waluyo, Bambang. 1996. Penelitian Hukum Dalam Praktek. Edisi ke-3. Sinar Grafika. Jakarta.

Amiruddin, Asikin, Zainal. 2003. Pengantar Metode Penelitian Hukum. Edisi-1. PT Raja Grafindo Persada. Jakarta. 
Program Studi Ilmu Hukum Universitas Putera Batam

Angkasa. 2010. Over Capacity Narapidana di Lembaga Pemasyaratakan, Faktor Penyebab, Implikasi Negatif, Serta Solusi Dalam Upaya Optimalisasi Pembinaan Narapidana. Vol. (10): 2

Eva Ahcjani Zulfa, 2014, Konsep Dasar Restorative Justice, disampaikan dalam acara pelatihan hukum Pidana dan Kriminologi "Asas-Asas Hukum Pidana Dan Kriminologi Serta Perkembangan Dewasa Ini”, Kerjasama Fakultas Hukum Universitas Gadjah Mada dengan Masyarakat Hukum Pidana dan Kriminologi. 23, Februari 2014, Yogyakarta. Hal. 1.

Nurhayati, N. 2009. Sistem Pidana Denda Dalam Kebijakan Legislatif di Indonesia. Tesis. Fakultas Hukum Universitas Diponegoro, Semarang.

Sucahyo, N. "Wamenkumham: Penjara Penuh, Pidana Penolak Vaksin Jadi Opsi Terakhir", https://www.voaindonesia.com/a/wamenkumham-penjarapenuh-pidana-penolak-vaksin-jadi-opsi-terakhir/5741553.html. Diakses tanggal 02 Januari 2021.

Ramadhan, R. "Dicopot dari Dirjen Pas, Utami Klaim Tekan "Overcapacity" Lapas", https://nasional.kompas.com/read/2020/03/05/17395071/dicopotdari-dirjen-pas-utami-klaim-tekan-overcapacity-lapas?page=all. Diakses tanggal 02 Januari 2021.

Fajriani, D. "MPR Minta Kelebihan Kapasitas Lapas Segera Dicarikan Solusi”, https://mediaindonesia.com/politik-dan-hukum/308042/mpr-minta-

Januari 2021.

kelebihan-kapasitas-lapas-segera-dicarikan-solusi. Diakses pada 03

Suwiknyo, E. "Overcapacity Lapas Disorot, Wamenkumham Beri Jawaban Begini”,

https://kabar24.bisnis.com/read/20210131/16/1350152/overcapacity-lapasdisorot-wamenkumham-beri-jawaban-begini. Diakses pada 03 Januari 2021.

Setiawan, A. "LP di Indonesia Over Capacity 45\%", https://news.okezone.com/read/2008/01/04/1/72751/lp-di-indonesia-overcapacity-45. Diakses pada 03 Januari 2021.

Hidayat, R. "Upaya Kemenkumham Atasi Persoalan Over Kapasitas Lapas", https://www.hukumonline.com/berita/baca/lt5e54f2a39fdd4/upayakemenkumham-atasi-persoalan-over-kapasitas-lapas/. Diakses pada 03 Januari 2021.

Mihardi. "Ditjen Pas Ungkap Empat Penyebab Lapas Kelebihan Kapasitas.", https://nasional.sindonews.com/berita/1161936/13/ditjen-pas-ungkapempat-penyebab-lapas-kelebihan-kapasitas. Diakses pada 04 Januari 2021.

Sistem Database Permasyaratakan Data Penghuni terakhir Perkanwil. http://smslap.ditjenpas.go.id/public/grl/current/monthly. Diakses pada 20 Januari 2021 